\title{
Proses Berpikir Siswa dalam Memecahkan Masalah Matematika Materi Sistem Persamaan Linear Tiga Variabel yang Ditinjau dari Tipe Kepribadian Keirsey
}

\author{
Rifni Anjani ${ }^{1}$, Damris, $\mathbf{M}^{2}$, Kamid ${ }^{3}$ \\ 1, 2, 3 Program Studi Pendidikan Matematika, Pascasarjana, Universitas Jambi \\ J1. Raden Mataher No. 16-Jambi, Kota Jambi, Indonesia \\ rifnianjani18@gmail.com
}

\begin{abstract}
This study aims to determine the students' thinking processes in solving mathematical problems with a threevariable system of linear equations in terms of Keirsey's personality type in class X IPA1 SMA Negeri 2 Muaro Jambi. This type of research is descriptive qualitative research. The research subjects consisted of 2 students from each personality type, guardian, artisan, rational, and idealist. Data collection methods are tests and interviews. The instruments used were the Keirsey personality type questionnaire as an instrument for selecting prospective research subjects, mathematical problem solving at problem sheets for three-variable linear equation systems, and interview guidelines. The data analysis technique in this study used Cresswell analysis. The results showed that each personality type has a different thought process. Guardian, artisan, and idealist personality types carry out assimilation and abstraction thinking processes in understanding problems, planning problem solving, and implementing problem solving as well as assimilation thinking processes in re-examining answers in Polya's problem solving step. Meanwhile, the rational personality type performs assimilation and abstraction thinking processes at each step of Polya's problem solving.
\end{abstract}

Keywords: Thinking Process, Problem Solving, Three Variable Linear Equation System, Personality Type

\begin{abstract}
Abstrak
Penelitian ini bertujuan untuk mengetahui proses berpikir siswa dalam memecahkan masalah matematika materi sistem persamaan linear tiga variabel yang ditinjau dari tipe kepribadian Keirsey di kelas X IPA1 SMA Negeri 2 Muaro Jambi. Jenis penelitian ini adalah penelitian kualitatif deskriptif. Subjek penelitian terdiri dari 2 siswa dari setiap tipe kepribadian guardian, artisan, rational, dan idealist. Metode pengambilan data adalah tes dan wawancara. Instrumen yang digunakan adalah angket tipe kepribadian Keirsey sebagai instrumen pemilihan calon subjek penelitian, lembar soal pemecahan masalah matematika pada materi sistem persamaan linear tiga variabel, dan pedoman wawancara. Teknik analisis data dalam penelitian ini menggunakan analisis Cresswell. Hasil penelitian menunjukkan bahwa setiap tipe kepribadian mempunyai proses berpikir yang berbeda. Tipe kepribadian guardian, artisan, dan idealist melakukan proses berpikir asimilasi dan abstraksi dalam memahami masalah, merencanakan pemecahan masalah, dan melaksanakan pemecahan masalah serta melakukan proses berpikir asimilasi dalam memeriksa kembali jawaban pada langkah pemecahan masalah Polya. Sedangkan tipe kepribadian rational melakukan proses berpikir asimilasi dan asbtraksi pada setiap langkah pemecahan masalah Polya.
\end{abstract}

Keywords: Proses Berpikir, Pemecahan Masalah, Sistem Persamaan Linier Tiga Variabel, Tipe Kepribadian

Copyright (c) 2021 Rifni Anjani, Damris, M, Kamid

$\triangle$ Corresponding author: Rifni Anjani

Email Address: rifnianjani18@gmail.com (Jl. Raden Mataher No. 16-Jambi, Kota Jambi, Indonesia)

Received 08 July 2021, Accepted 23 August 2021, Published 23 August 2021

\section{PENDAHULUAN}

Pada umumnya manusia cenderung menyukai segala sesuatu yang serba instan. Hal ini juga mempengaruhi manusia untuk selalu berpikir cepat dan praktis dalam segala hal, termasuk dalam hal pendidikan. Saat ini banyak siswa yang lebih mementingkan bagaimana mendapatkan nilai bagus tanpa memperdulikan ilmu apa yang mereka pelajari. Begitu juga dalam pembelajaran matematika, siswa cenderung memilih cara cepat dalam menyelesaikan masalah tanpa memperdulikan proses penyelesaiannya. 
Kesulitan siswa untuk mempelajari matematika dikarenakan materi yang dipelajari sering dirasa abstrak. Untuk mengatasinya, perlu dilakukan berbagai macam upaya diantaranya dengan memberikan metode mengajar yang sesuai bagi siswa. Dalam kegiatan proses pembelajaran dikelas banyak sekali berbagai sifat dan kepribadian yang akan ditemui. Karena setiap orang termasuk siswa memiliki sifat dan kepribadian yang berbeda-beda. Sifat dan kepribadian yang berbeda-beda tersebutlah yang mempengaruhi cara belajar dan kegiatan belajar siswa itu sendiri. Fathoni dalam (Ramalisa, 2013) menjelaskan bahwa karakteristik siswa yang dapat mempengaruhi kegiatan belajar siswa antara lain sebagai berikut : latar belakang, taraf pengetahuan, gaya belajar, proses berpikir, usia, kronologi, kepribadian, tingkat kematangan, keyakinan, lingkungan, sosial ekonomi dan lain sebagainya.

Dari pendapat tersebut dapat dilihat bahwa salah satu karakteristik siswa yang dapat mempengaruhi kegiatan belajar siswa adalah proses berpikir. Pemahaman tentang proses berpikir yang dimiliki siswa dapat menjadi salah satu sumber informasi bagi guru dalam mengajar. Nurlastyaningtyas(2016) menjelasakan, dengan mengetahui proses berpikir yang dimiliki siswa, maka guru dapat mengungkapkan bagaimana proses yang berjalan dalam pikiran siswa ketika mereka memecahkan masalah. Dari proses tersebut akan diketahui bagaimana proses berpikir yang terjadi dan guru dapat merancang model pembelajaran yang efisien dan memudahkan siswa dalam memahami konsep sehingga tujuan dari pembelajaran dapat tercapai.

Suparno(2001) mengatakan bahwa proses berpikir terjadi dalam otak manusia dengan melibatkan dua komponen yaitu informasi yang masuk dan skema yang telah dibentuk dalam pikiran. Pada proses berpikir skema merupakan sebuah rangkaian proses yang dipengaruhi pengalaman dan pengetahuan yang diperoleh, sehingga selalu mengalami perkembangan. Penyesuaian informasi baru dengan skema yang sudah ada dalam otak disebut adaptaasi. Proses adaptasi dibedakan menjadi dua yaitu asimilasi dan akomodasi serta pembentukan skema yang betul-betul baru yang disebut abstraksi. Proses abstraksi setiap siswa seharusnya dilakukan oleh guru. Pada saat seorang ghuru mengetahui proses berpikir siswa, guru mencari tahu letak kesalahan dan jenis kesalahan yang dilakukan siswa sehingga guru dapat memperbaiki pemahaman siswa melalui proses pembelajaran.

Proses berpikir siswa dalam menyelesaikan soal dapat dilihat dalam pemecahan masalah atau penyelesaian masalah yang dilakukan siswa dalam mengerjakan soal (Retna, Milda., Lailatul Mubarokah, 2013). National Council of Teachers of Mathematics (NCTM, 2000) menjelaskan terdapat lima kemampuan dasar matematika yakni pemecahan masalah (problem solving), penalaran dan bukti (reasoning and proof), koneksi (connection), dan representasi (repretantion).

Sabandar (2009) menyatakan bahwa untuk melatih kemampuan berpikir maka siswa harus dihadapkan pada masalah-masalah yang sifatnya menantang siswa, atau dengan fakta lain harus menjadikan siswa sebagai seorang pemecah masalah yang baik. Tentunya masalah yang diberikan merupakan masalah matematika. Diana (2013)mengemukakan bahwa masalah dalam matematika adalah sebuah pertanyaan yang tidak mampu diselesaikan dengan prosedur rutin melainkan menggunakan berbagai keterampilan dan pengetahuan yang dimiliki untuk memecahkannya. 
Pemecahan masalah menjadi penting dalam tujuan pendidikan matematika disebabkan karena dalam kehidupan sehari-hari manusia memang tidak pernah dapat lepas dari suatu masalah. Aktivitas dalam memecahkan masalah dapat dianggap suatu aktivitas dasar manusia. Dengan pemecahan masalah siswa dimungkinkan memperoleh pengalaman menggunakan pengetahuan serta keterampilan yang sudah dimiliki untuk diterapkan pada pemecahan masalah yang bersifat tidak rutin. Melalui kegiatan pemecahan masalah aspek-aspek yang penting dalam pembelajaran matematika dapat dikembangkan dengan baik.

Penyelesaian masalah dalam penelitian ini adalah usaha menemukan solusi atau jawaban dari masalah yang diberikan dengan menggunakan pengetahuan atau konsep matematika yang telah dimiliki sebelumnya. Penyelesaian masalah dalam penelitian ini menggunakan langkah Polya (1973) yaitu: (1) memahami masalah; (2) merancang rencana penyelesaian; (3) melaksanakan rencana penyelesaian; dan (4) memeriksa kembali. Proses yang digunakan untuk menyelesaikan masalah matematika Polya adalah siswa melakukan proses berpikir. Proses berpikir yang dilakukan siswa yaitu ketika mengumpulkan informasi dari sebuah masalah yaitu memahami masalah. Untuk membuat rancangan penyelesaian masalah diperlukan informasi, sehingga siswa akan menyelesaikan masalah sesuai rancangan yang telah dibuat. Setelah itu siswa akan memeriksa kembali jawaban dari pemecahan masalah yang telah diselesaikan.

Ternyata, berdasarkan hasil pengamatan terhadap kondisi siswa akan membuahkan suatu kesimpulan bahwa setiap siswa selalu mempunyai perbedaan. Perbedaan tersebut paling mudah diamati dalam tingkah laku secara nyata. Pengajar tentu pernah melihat di mana terdapat siswa yang selalu terlihat aktif, ada siswa yang terlihat pasif, dan ada juga yang tidak memperhatikan sama sekali. Pada saat mengerjakan soal ada siswa yang langsung mengerjakan soal, ada juga yang harus dibantu sama temannya yang lain, dan ada juga yang tidak mengerjakan sama sekali. Perbedaan ini tercermin dari tingkah laku dan interaksi siswa serta guru. Sehingga ada beberapa model pembelajaran yang diberikan guru tidak sesuai dan ada juga yang sesuai dengan siswa. Perbedaan tingkah laku inilah yang membentuk karakteristik siswa yang menimbulkan suatu perbedaan kepribadian. Tingkah laku siswa dapat dilihat dari cara berpikir siswa dalam menghadapi soal.

Perbedaan tingkah laku pada setiap individu, baik guru maupun siswa terjadi karena pengaruh dari kepribadian yang berbeda-beda. Berpangkal pada kenyataan, bahwa kepribadian manusia itu sangat bermacam-macam, bahkan mungkin sama banyak dengan banyaknya orang, segolongan ahli berusaha menggolong-golongkan manusia itu ke dalam tipe-tipe tertentu, karena mereka berpendapat bahwa cara itulah yang paling efektif untuk mengenal sesama manusia dengan baik.

Keirsey, D., \& Bates (1984) dalam tipe kepribadian Keirsey, Keirsey membagi kepibadiannya menjadi 4 tipe kepribadian, yaitu tipe Guardian, tipe Artisan, tipe Rational dan tipe Idealist yang berdasarkan temperament sorter. Temperament sorter adalah instumen kepribadian yang paling banyak digunakan untuk mengetahui kepribadian seseorang melalui pertanyaan-pertanyaan yang kuat untuk membantu individu untuk menemukan tipe kepriadian seseorang. Menurut Agustin (2019) kepribadian 
keirsey adalah kepribadian yang menggolongkan tipe kepribadiannya berdasarkan pada pola tingkah laku yang nampak, namun lebih pada cara seseorang berfikir. Maka sangatlah perlu di mengerti untuk mengetahui bagaimana proses berfikir siswa yang dilihat dari masing-masing tipe kepribadian siswa yang ditinjau dari Kepribadian keirsey.

\section{METODE}

Penelitian ini merupakan penelitian kualitatif deskriptif. Menurut Creswell, J. W., \& Poth, (2016) metode penelitian kualitatif merupakan metode-metode untuk mengeskplorasi dan memahami makna yang oleh sejumlah individu atau sekelompok orang dianggap berasal dari masalah sosial atau kemanusiaan. Proses penelitian kualitatif ini melibatkan upaya-upaya penting seperti mengajukan pertanyaan dan prosedur-prosedur, mengumpulkan data yang spesifikdari partisipan, menganalisis data secara induktif mulai dari tema-tema yang khusus ke tema-tema umum, dan menafsirkan data. Prosedur penelitian yang dilaksanakan dalam penelitian ini mengacu pada tahap atau prosedur penelitian menurut Bogdan yang dimodifikasi oleh Moleong,(2013). Tahap penelitian tersebut meliputi: (1) tahap pralapangan, (2) tahap pekerjaan lapangan, dan (3) tahap analisis data. Prosedur penelitian yang dilakukan dapat dilihat pada Gambar 1.

1

Tahap Pra-Lapangan

-Permintaan izin untuk melakukan

- Penyusunan instrumen penelitian

-Validasi instrumen penelitian yang berupa soal tes dan pedoman wawancara

2

Tahap Pekerjaan Lapangan

-Melakukan tes pemilihan subjek

- Menganalisa jawaban siswa dan menentukan subjek penelitian

- Melakukan tes soal materi sistem persamaan linear tiga variabel

- Melakukan wawancara kepada subjek penelitian

\section{3}

Tahap Analisis Data

-Data yang diperoleh dalam penelitian ini selanjutnya dianalisis sesuai dengn teknik analisis data

Gambar 1. Prosedur Penelitian

Subjek penelitiannya adalah siswa kelas X IPA 1 SMA Negeri 2 Muaro Jambi yang terdiri dari delapan siswa. Pemilihan subjek menggunakan teknik pemilihan sampel bertujuan (purposive sampling) dan didasarkan pada diskusi dan pertimbangan bersama guru serta kelancaran komunikasi (lisan dan tulisan) siswa. Untuk pengelompokan siswa ke dalam empat tipe kepribadian yaitu guardian, artisan, rational, dan idealist digunakan angket temperament sorter yaitu instumen kepribadian yang paling banyak digunakan untuk mengetahui kepribadian seseorang melalui pertanyaan-pertanyaan yang kuat untuk membantu individu menemukan tipe kepriadiannya. Lembar tes kepribadian ini diisi oleh 30 siswa 
dan dipilih dua siswa dari masing-masing tipe kepribadian. Dalam penelitian ini, instrumen utama adalah peneliti sendiri. Soal tes pemecahan masalah matematika dan pedoman wawancara sebagai instrument pendukung.

Pengumpulan data dalam penelitian ini dilakukan dengan menggunakan metode wawancara semiterstruktur yang dilakukan oleh peneliti sendiri kepada setiap subjek ketika menyelesaikan soal pemecahan masalah dengan langkah-langkah Polya. Menurut Moleong (2013) wawancara semi terstruktur adalah wawancara yang menggunakan beberapa inti pertanyaan, namun dalam pelaksanaannya peneliti mengajukan pertanyaan secara bebas, pertanyaan tidak perlu ditanyakan secara berurutan dan pemilihan kata-katanya tidak baku tetapi dimodifikasi sesuai situasi. Untuk memeriksa keabsahan data yang diperoleh maka digunakan uji kredibilitas data dengan cara triangulasi.

Triangulasi yang digunakan dalam penelitian ini adalah triangulasi sumber dan triangulasi teknik. Teknik analisis data yang digunakan dalam penelitian ini adalah analisis data kualitatif mengikuti konsep Creswell, J. W., \& Poth (2016) yaitu mengolah dan mempersiapkan data untuk dianalisis, membaca keseluruhan data, memulai coding semua data, merapkan proses coding untuk mendeskripsikan setting, orang, kategori, dan tema yang akan dianalisis, menunjukkan bagaimana deskripsi dan tema-tema ini akan disajikan kembali dalam laporan, dan pembuatan interpretasi.

\section{HASIL DAN DISKUSI}

\section{Proses Berpikir Siswa Tipe Guardian}

Analisis proses berpikir siswa guardian dalam memecahkan masalah matematika pada soal satu sudah mengacu pada langkah-langkah Polya, dimulai dari proses berpikir siswa dalam memahami masalah, menyusun recana penyelesaian, menyelesaikan masalah sesuai perencanaan, sampai memeriksa kembali hasil yang telah diperoleh. Berdasarkan hasil analisis data diperoleh hasil bahwa siswa guardian dalam memahami masalah baik pada soal pertama, soal kedua, dan soal ketiga terlihat bahwa siswa dapat menuliskan informasi yang terdapat pada soal dengan benar yaitu menuliskan apa yang diketahui dan apa yang ditanyakan pada ketiga soal tersebut. Siswa guardian juga membuat pemisalan dengan simbol huruf untuk variabel yang dijelaskan pada soal dan juga menuliskan apa yang ditanyakan pada soal dan ditulis secara runtut dan jelas namun pada soal satu siswa G2 tidak menuliskan apa yang diketahui. Pada langkah merencanakan pemecahan masalah terlihat bahwa siswa guardian dapat mengubah kalimat matematika yang ada pada soal menjadi model matematika sehingga membentuk sistem persamaan linear tiga variabel, siswa dapat menjelaskan dan menuliskan dengan benar dan lancar cara menyelesaikan soal, serta menyajikan langkah penyelesaian dengan benar. Pada langkah melaksanakan rencana siswa dapat memilih metode penyelesaian dengan tepat sehingga dapat algoritma perhitungan yang dilakukan juga benar pada soal pertama, soal kedua, dan soal ketiga. Dari penjelasan tersebut dapat diketahui bahwa siswa guardian dapat mengitegrasikan secara langsung informasi atau pengetahuan barunya ke dalam skema yang ada dipikirannya. Dengan demikian dapat dikatakan bahwa siswa guardian melakukan proses berpikir asimilasi dan abstraksi dalam memahami 
masalah, merencanakan pemecahan masalah, dan melaksanakan rencana pemecahan masalah.

Hal ini juga senada dengan yang dikemukan Blake, B., \& Tambara,(2008)yang mengatakan bahwa asimilasi adalah proses pengintegrasian masalah yang dihadapi ke dalam struktur kognitif yang sudah ada sebelumnya, karena struktur masalah yang dihadapi sesuai dengan skema yang sudah dimiliki. Sedangkan Gray, E., \& Tall, (2007)menjelaskan salah satu langkah abstraksi yaitu fokus pada kegiatan objek, yang mengarah pada operasi simbol dalam aritmatika, aljabar, maupun kalkulus.

Pada langkah terakhir memeriksa kembali jawaban dapat diketahui bahwa siswa guardian memeriksa kembali jawaban dan dapat menuliskan kesimpulan dengan benar. Selain itu siswa juga meyakini kebenaran dari hasil yang telah diperoleh. Dari penjelasan tersebut dapat diketahui bahwa siswa guardian dapat mengitegrasikan secara langsung informasi atau pengetahuan barunya ke dalam skema yang ada dipikirannya. Dengan demikian dapat dikatakan bahwa siswa guardian melakukan proses berpikir asimilasi dalam memeriksa kembali jawaban.

\section{Proses Berpikir Siswa Tipe Artisan}

Berdasarkan hasil analisis data diperoleh hasil bahwa siswa artisan dalam memahami masalah baik pada soal pertama, soal kedua, dan soal ketiga terlihat bahwa siswa dapat menuliskan informasi yang terdapat pada soal dengan benar yaitu menuliskan apa yang diketahui dan apa yang ditanyakan pada ketiga soal tersebut. Siswa artisan juga membuat pemisalan dengan simbol huruf untuk variabel yang dijelaskan pada soal dan juga menuliskan apa yang ditanyakan pada soal dan ditulis secara runtut dan jelas namun pada soal satu dan soal tiga siswa A2 tidak menuliskan apa yang diketahui. Pada langkah merencanakan pemecahan masalah terlihat bahwa siswa artisan dapat mengubah kalimat matematika yang ada pada soal menjadi model matematika sehingga membentuk sistem persamaan linear tiga variabel, siswa dapat menjelaskan dan menuliskan dengan benar dan lancar cara menyelesaikan soal, namun A1 tidak dapat menyajikan langkah penyelesaian dengan benar pada soal satu dan soal tiga. Pada langkah melaksanakan rencana siswa dapat memilih metode penyelesaian dengan tepat sehingga algoritma perhitungan yang dilakukan juga benar pada soal pertama, soal kedua, dan soal ketiga namun siswa A1 tidak dapat menggunakan algoritma perhitungan yang benar pada soal satu dan soal tiga. Dari penjelasan tersebut dapat diketahui bahwa siswa artisan dapat mengitegrasikan secara langsung informasi atau pengetahuan barunya ke dalam skema yang ada dipikirannya. Dengan demikian dapat dikatakan bahwa siswa artisan melakukan proses berpikir asimilasi dan abstraksi dalam memahami masalah, merencanakan pemecahan masalah, dan melaksanakan rencana pemecahan masalah.

Hal ini juga senada dengan yang dikemukan Blake, B., \& Tambara, (2008) yang mengatakan bahwa asimilasi adalah proses pengintegrasian masalah yang dihadapi ke dalam struktur kognitif yang sudah ada sebelumnya, karena struktur masalah yang dihadapi sesuai dengan skema yang sudah dimiliki. Sedangkan Gray, E., \& Tall, (2007) menjelaskan salah satu langkah abstraksi yaitu fokus pada kegiatan objek, yang mengarah pada operasi simbol dalam aritmatika, aljabar, maupun kalkulus.

Pada langkah terakhir memeriksa kembali jawaban dapat diketahui bahwa siswa artisan memeriksa kembali jawaban dan dapat menuliskan kesimpulan dengan benar namun siswa A1 pada soal 
satu dan soal tiga tidak dapat membuat kesimpulan dengan benar. Selain itu siswa juga meyakini kebenaran dari hasil yang telah diperoleh. Dari penjelasan tersebut dapat diketahui bahwa siswa artisan dapat mengitegrasikan secara langsung informasi atau pengetahuan barunya ke dalam skema yang ada dipikirannya. Dengan demikian dapat dikatakan bahwa siswa artisan melakukan proses berpikir asimilasi dalam memeriksa kembali jawaban

\section{Proses Berpikir Siswa Tipe Rational}

Berdasarkan hasil analisis data diperoleh hasil bahwa siswa rational dalam memahami masalah baik pada soal pertama, soal kedua, dan soal ketiga terlihat bahwa siswa dapat menuliskan informasi yang terdapat pada soal dengan benar yaitu menuliskan apa yang diketahui dan apa yang ditanyakan pada ketiga soal tersebut namun pada soal 1 siswa R1 tidak menuliskan apa yang diketahui pada soal. Siswa rational juga menuliskan apa yang ditanyakan pada soal dan ditulis secara runtut dan jelas. Pada langkah merencanakan pemecahan masalah terlihat bahwa siswa rational dapat mengubah kalimat matematika yang ada pada soal menjadi model matematika sehingga membentuk sistem persamaan linear tiga variabel, siswa dapat menjelaskan dan menuliskan dengan benar dan lancar cara menyelesaikan soal, serta menyajikan langkah penyelesaian dengan benar. Pada langkah melaksanakan rencana siswa dapat memilih metode penyelesaian dengan tepat sehingga dapat algoritma perhitungan yang dilakukan juga benar pada soal pertama, soal kedua, dan soal ketiga. Dari penjelasan tersebut dapat diketahui bahwa siswa rational dapat mengitegrasikan secara langsung informasi atau pengetahuan barunya ke dalam skema yang ada dipikirannya. Dengan demikian dapat dikatakan bahwa siswa rational melakukan proses berpikir asimilasi dan abstraksi dalam memahami masalah, merencanakan pemecahan masalah, dan melaksanakan rencana pemecahan masalah.

Hal ini juga senada dengan yang dikemukan Blake, B., \& Tambara, (2008)yang mengatakan bahwa asimilasi adalah proses pengintegrasian masalah yang dihadapi ke dalam struktur kognitif yang sudah ada sebelumnya, karena struktur masalah yang dihadapi sesuai dengan skema yang sudah dimiliki. Sedangkan Gray, E., \& Tall, (2007) menjelaskan salah satu langkah abstraksi yaitu fokus pada kegiatan objek, yang mengarah pada operasi simbol dalam aritmatika, aljabar, maupun kalkulus.

Pada langkah terakhir memeriksa kembali jawaban dapat diketahui bahwa siswa rational memeriksa kembali jawaban dan dapat menuliskan kesimpulan dengan benar. Selain itu siswa juga meyakini kebenaran dari hasil yang telah diperoleh. Dari penjelasan tersebut dapat diketahui bahwa siswa rational dapat mengitegrasikan secara langsung informasi atau pengetahuan barunya ke dalam skema yang ada dipikirannya. Dengan demikian dapat dikatakan bahwa siswa rational melakukan proses berpikir asimilasi dan abstraksi dalam memeriksa kembali jawaban.

\section{Proses Berpikir Siswa Tipe Idealist}

Berdasarkan hasil analisis data diperoleh hasil bahwa siswa idealist dalam memahami masalah baik pada soal pertama, soal kedua, dan soal ketiga terlihat bahwa siswa hanya dapat menuliskan informasi yang apa yang ditanyakan pada soal. Siswa idealist juga menuliskan apa yang ditanyakan pada soal dan ditulis secara runtut dan jelas tetapi siswa tidak menuliskan apa yang diketahui pada soal. Pada langkah 
merencanakan pemecahan masalah terlihat bahwa siswa idealist dapat mengubah kalimat matematika yang ada pada soal menjadi model matematika sehingga membentuk sistem persamaan linear tiga variabel, siswa dapat menjelaskan dan menuliskan dengan benar dan lancar cara menyelesaikan soal, serta menyajikan langkah penyelesaian dengan benar. Namun pada soal tiga siswa I1 tidak dapat merencanakan penyelesaian dengan baik. Pada langkah melaksanakan rencana siswa dapat memilih metode penyelesaian dengan tepat sehingga dapat algoritma perhitungan yang dilakukan juga benar pada soal pertama, soal kedua, dan soal ketiga tetapi tidak pada siswa I1 belum dapat melakukan perhitungan dengan tepat. Dari penjelasan tersebut dapat diketahui bahwa siswa idealist dapat mengitegrasikan secara langsung informasi atau pengetahuan barunya ke dalam skema yang ada dipikirannya. Dengan demikian dapat dikatakan bahwa siswa idealist melakukan proses berpikir asimilasi dan abstraksi dalam memahami masalah, merencanakan pemecahan masalah, dan melaksanakan rencana pemecahan masalah.

Hal ini juga senada dengan yang dikemukan Blake, B., \& Tambara, (2008)yang mengatakan bahwa asimilasi adalah proses pengintegrasian masalah yang dihadapi ke dalam struktur kognitif yang sudah ada sebelumnya, karena struktur masalah yang dihadapi sesuai dengan skema yang sudah dimiliki. Sedangkan Gray, E., \& Tall,(2007) menjelaskan salah satu langkah abstraksi yaitu fokus pada kegiatan objek, yang mengarah pada operasi simbol dalam aritmatika, aljabar, maupun kalkulus.

Pada langkah terakhir memeriksa kembali jawaban dapat diketahui bahwa siswa idealist memeriksa kembali jawaban dan dapat menuliskan kesimpulan dengan benar. Selain itu siswa juga meyakini kebenaran dari hasil yang telah diperoleh. Namun siswa I1 belum dapat membuat kesimpulan dengan benar. Dari penjelasan tersebut dapat diketahui bahwa siswa idealist dapat mengitegrasikan secara langsung informasi atau pengetahuan barunya ke dalam skema yang ada dipikirannya. Dengan demikian dapat dikatakan bahwa siswa idealist melakukan proses berpikir asimilasi dalam memeriksa kembali jawaban.

\section{KESIMPULAN}

Berdasarkan hasil penelitian diperoleh beberapa kesimpulan yaitu 1) Siswa yang mempunyai tipe kepribadian guardian melakukan proses berpikir asimilasi dan abstraksi pada langkah memahami masalah, merencanakan pemecahan masalah, dan melaksanakan. Akan tetapi pada langkah memeriksa kembali jawaban siswa tipe guardian melakukan proses berpikir asimilasi berdasarkan langkah pemecahan masalah polya. 2) Siswa yang mempunyai tipe kepribadian artisan melakukan proses berpikir asimilasi dan abstraksi pada langkah memahami masalah, merencanakan pemecahan masalah, dan melaksanakan. Akan tetapi pada langkah memeriksa kembali jawaban siswa tipe artisan melakukan proses berpikir asimilasi berdasarkan langkah pemecahan masalah polya. 3) Siswa yang mempunyai tipe kepribadian rational melakukan proses berpikir asimilasi dan abstraksi pada setiap langkah pemecahan masalah polya. 4) Siswa yang mempunyai tipe kepribadian idealist melakukan proses berpikir asimilasi dan abstraksi pada langkah memahami masalah, merencanakan pemecahan masalah, 
dan melaksanakan. Akan tetapi pada langkah memeriksa kembali jawaban siswa tipe idealist melakukan proses berpikir asimilasi berdasarkan langkah pemecahan masalah polya.

\section{UCAPAN TERIMA KASIH}

Peneliti mengucapkan syukur kepada Allah SWT karena telah diberikan kelancaran menyelesaikan artikel ini. Kemudian berterima kasih juga kepada orang tua Bapak M. Arif, SE., dan Ibu Yani Sundarsih, S.Pd., serta suami Dani Riduanda, SE., yang telah memberikan dukungan selalu. Terima kasih kepada dosen pembimbing Prof. Drs. Damris M, M.Sc., Ph.D., dan Dr. Drs. Kamid, M.Si., yang telah memberikan arahan dan masukan sampai artikel ini selesai.

\section{REFERENSI}

Agustin, M. D. A. (2019). Proses Berfikir Matematis Siswa Dalam Memecahkan Masalah Matematika Ditinjau Dari Tipe Kepribadian Keirsey. Madrosatuna: Journal of Islamic Elementary School, 2(2), 29-38.

Blake, B., \& Tambara, P. (2008). Developmental Psychology: Incorporating Piaget's And Vygotsky's Theories In Classrooms. Journal Of Cros-Disciplinary Pcrspective In Education.

Creswell, J. W., \& Poth, C. N. (2016). Qualitative inquiry and research design: Choosing among five approaches. Sage publications.

Diana, N. (2013). Kreatifitas Siswa SMP Dalam Pemecahan Masalah Matematika Terbuka Ditinjau dari Gaya Belajar. Surabaya: Makalah Komprehensif No: 189 MKL. 13PPS UNESA.

Gray, E., \& Tall, D. (2007). Abstraction as a Natural Process of Mental C o m p r e s s i o n. 19(2), 2340.

Keirsey, D., \& Bates, M. M. (1984). Please Understand Me: Character and Temperament Types. Del Mar, CA: Prometheus Nemesis Book Company., 210.

Moleong, L. J. (2013). Metodologi Penelitian Kualitatif. PT. Remaja Rosdakarya.

NCTM. (2000). Principle and Standart for School Mathematics. Reston: The National Council of Teachers of Mathematics, Inc.

Nurlastyaningtyas, M. (2016). Profil Proses Berpikir Siswa Dalam Menyelesaikan Soal-Soal Pythagoras Ditinjau Dari Gaya Belajar Dan Gaya Kognitif (Doctoral dissertation, Universitas Muhammadiyah Surakarta). Naskah Publikasi.

Polya, G. (1973). How to solve it. New Jersey: Princeton Science Library. Princeton Science Library.

Ramalisa, Y. (2013). Proses berpikir kritis siswa SMA tipe kepribadian thinking dalam memecahkan masalah matematika. Edumatica: Jurnal Pendidikan Matematika, 3(01)., Volume 03.

Retna, Milda., Lailatul Mubarokah, dan S. (2013). Proses Berpikir Siswa dalam Menyelesaikan Soal Cerita Ditinjau Berdasarkan Kemampuan Matematika (The Student Thinking Process in Solving Math Story Problem). Jurnal Pendidikan Matematika STKIP PGRI Sidoarjo, 1(2): 71-82.

Sabandar, J. (2009). Thinking Classroom Dalam Pembelajaran Matematika di Sekolah. 
Proses Berpikir Siswa dalam Memecahkan Masalah Matematika Materi Sistem Persamaan Linear Tiga Variabel yang Ditinjau dari Tipe Kepribadian Keirsey, Rifni Anjani, Damris, M, Kamid

http://math.sps.upi.edu.

Suparno, P. (2001). Teori perkembangan kognitif jean piaget. Kanisius. Kanisius. 